\title{
Novel insights to the anti-proliferative activity of rosemary (Rosmarinus officinalis L.) co-treatment
}

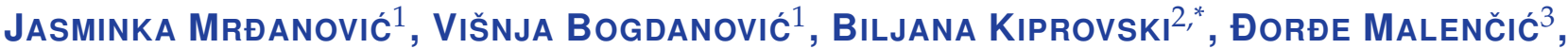 \\ Maja Mikulič-PetKovšek ${ }^{4}$, IVAn Milovanović ${ }^{5}$, ANd Aleksandra Mišan ${ }^{5}$ \\ ${ }^{1}$ University of Novi Sad, Faculty of Medicine, Oncology Institute of Vojvodina, Put dr Goldmana 4, 21204 Sremska Kamenica, Serbia \\ ${ }^{2}$ Institute of Field and Vegetable Crops, Maksima Gorkog 30, 21000 Novi Sad, Serbia \\ ${ }^{3}$ University of Novi Sad, Faculty of Agriculture, Department of Field and Vegetable Crops, Trg Dositeja Obradovića 8, 21000 Novi Sad, Serbia \\ ${ }^{4}$ University of Ljubljana, Biotechnical faculty, Department of Agronomy, Chair for Fruit, Wine and Vegetable Growing, Jamnikarjeva 101, 1000 SI-Ljubljana, \\ Slovenia \\ ${ }^{5}$ Institute of Food Technology, Bulevar Cara Lazara 1, 21000 Novi Sad, Serbia \\ *Corresponding author: bkiprovski@gmail.com
}

Received: April 24, 2019

Accepted: November 11, 2019

Published on-line: December 15, 2019

Published: December 25, 2019

\begin{abstract}
The aim of this study was to characterize volatile and non-volatile compounds of rosemary from the North Adriatic region and to determine its antiproliferative activity, alone or in combination with radiomimetic bleomycin (BLM) on three malignant and one non-transformed human cell lines. Chemical analysis of the volatile compounds revealed the presence of monoterpenes (93.8\%), among which 1.8-cineol (32.9\%) and camphor (15.5\%) were the dominant compounds. Also, obtained results showed that the major polyphenolic constituents in rosemary extract were phenolic acids (rosmarinic acid and its derivatives up to $69.2 \mathrm{mg} 100 \mathrm{~g}^{-1}$ ), as well as flavones and flavonols in the following order: luteolin>isorhamnetin>quercetin >kaempferol>apigenin. Cell growth tests showed that rosemary extract alone exerted moderate antiproliferative activity, as well as a synergistic antiproliferative effect with bleomycin $\left(E_{50} 344.3-461.5 \mu \mathrm{g} \mathrm{mL} \mathrm{L}^{-1}\right.$ and $58.6-292 \mu \mathrm{gL}^{-1}$, respectively). The anti-tumor effect of rosemary extract in combination with BLM was much stronger, compared to BLM itself on the breast cancer cells. Through its proposed sensitizing effect, rosemary extract, in combination with the standard chemotherapeutics, could be used for the investigations of possible therapeutic modalities.
\end{abstract}

Key words: cell growth; essential oil profile; polyphenolics; rosemary

http://dx.doi.org/10.5937/leksir1939044M

\section{INTRODUCTION}

Among numerous spices and medicinal plants which are considered a promising source of natural products and various bioactivities, Rosmarinus officinalis L. has been frequently reported for its antiproliferative activity. In rosemary extracts numerous components have been found and their content depends on geographical origin (e.g. humidity, salinity, insolation), cultivar and extraction methods. These ingredients have a variety of extremely useful medicinal properties such as anti-inflammatory, anti-allergic, anti-irritant, antibacterial, antifungal, antioxidant and the most important for this investigation, anticancer (Leal et al., 2003; Kabouche et al., 2005; Peng et al., 2005).

Primary bioactive principles of rosemary are: rosmarinic acid, flavonoids and phenolic diterpens (carnosic acid and carnosol) (Petiwala and Johnson, 2015). Essential oil also has remarkable chemopreventive and anticancerogenic properties through mechanisms such as antioxidant, antimutagenic, antiprolif- erative and immunostimulatory mechanism of volatile constituents (Ali et al., 2015).

Biological activity of rosemary and its constituents was investigated in numerous in vitro and in vivo studies using tumor models. Antiproliferative and colony forming abilities of rosemary were observed on many various cell lines including leukemia (Cheung and Tai, 2007; Okumura et al., 2012), prostate (Petiwala et al., 2014) and ovarian cancer (Tai et al., 2012). Also, a number of studies regarding apoptosis and cell death showed that treatment with rosemary extracts had significantly reduced viability in various cell lines (Tai et al., 2012; González-Vallinas et al., 2013; 2014). Furthermore, antioxidative properties of rosemary in in vitro tumor cell models (Slameňová et al., 2002; Alexandrov et al., 2006; Cheung and Tai, 2007), as well as in vivo studies in experimental animals with induced cancer were confirmed (Sancheti and Goyal, 2006).

Flavones present in rosemary are potent antiproliferative com- 
pounds whose activity is based on balance between their antioxidative properties on one side, and their effect as prooxidants and mitochondrial toxic agents on the other (Haddad et al., 2006).

Also, caffeic and rosmarinic acid possess multiple biological properties such as anti-inflammatory, antimicrobial, cardioprotective and antitumor (Prasad et al., 2011; Bittner Fialová et al., 2019). Recent in vivo studies showed that rosmarinic acid dosedependently suppresses growth of pancreatic cancer cells from xenograft nude mice (Han et al., 2019). Also, it is known that rosemary constituents potentiate the effectiveness of conventional chemotherapeutics as well as other compounds of plant origin through synergistic influence (Lewandowska et al., 2014). Based on their investigations on a panel of colon cells, Borrás-Linares et al. (2015) put forward a theory about the synergistic action of rosemary extract ingredients. As it is described by some authors (Ivanova et al., 2014a; Plouzek et al., 1999), chemo-sensitising is the effect when biologically active molecule increases the activity of chemotherapeutic in tumour cells. Therefore, we included radiomimetic antitumor drug bleomycin in treatment of cell lines with rosemary extract. Namely, bleomycin, as free radical-based DNA damaging agent, induces a double-strand breaks on deoxyribose moieties in both DNA strands, interruption that is highly similar to those of ionizing radiation (Povirk, 1996).

Having in mind the antitumor potential of rosemary constituents and a lack of data concerning this medicinal plant collected from the North Adriatic region, this study was conducted to characterize volatile and non-volatile compounds of rosemary harvested from the region of the Krk island (North Adriatic). Secondarily, our aim was to evaluate antiproliferative activity of these compounds, alone or in combination with bleomycin against human cell lines - one non-transformed human cell line MRC-5 and three malignant MCF-7 (breast adenocarcinoma), HeLa (cervix epitheloid carcinoma) and HT-29 (colon adenocarcinoma) cell lines.

\section{MATERIALS AND METHODS}

\subsection{Plant material}

Aerial parts of the tested wild growing Rosmarinus officinalis were collected at Mali Kijec-Omišalj, Krk Island (Croatia), located in the Northern Adriatic (GPS coordinates $32^{\circ} 59^{\prime} 59.8^{\prime \prime} N 148^{\circ} 15^{\prime} 44.3^{\prime \prime} E$ ) in early June right before full blossoming. Voucher specimen was confirmed and deposited at the Herbarium of the Department of Biology and Ecology, Faculty of Sciences, University of Novi Sad, Serbia (Voucher N 2-1527). Plants were air dried in shade, and after that pulverized in a mortar with pestle and a coffee mill and used for further analyses.

\subsection{Determination of individual essential oil components using GC-MS analysis}

The essential oil was isolated by hydrodistillation method using $n$-hexane as collecting solvent, according to European Pharmacopoeia (Ph.Eur.8.0, 2013). The obtained hexane extract was dried over anhydrous sodium sulphate and decanted. Hexane was evaporated under reduced pressure and the oil yield was measured.

Gas chromatography-mass spectrometry (GC-MS) analysis was carried out using Agilent 5975C Series GC-MSD system (7890A GC and 5975C inert MSD), equipped with a HP-5MS capillary column $(30 \mathrm{~m} \times 0.25 \mathrm{~mm}$; film thickness $0.50 \mu \mathrm{m})$. One $\mu \mathrm{L}$ of diluted essential oil (100 times in $n$-heptane) was injected in split mode (10:1), and inlet temperature was held at $250{ }^{\circ} \mathrm{C}$. Helium was used as carrier gas in constant flow mode at $1 \mathrm{~mL} \mathrm{~min}^{-1}$. The oven temperature was programmed as follows: $70{ }^{\circ} \mathrm{C}$ increased to $104{ }^{\circ} \mathrm{C}\left(2{ }^{\circ} \mathrm{C} \mathrm{min}-1\right)$ which was held for $2 \mathrm{~min}$, then to $180{ }^{\circ} \mathrm{C}\left(2{ }^{\circ} \mathrm{C} \mathrm{min}^{-1}\right.$ without holding $)$, and then to $200^{\circ} \mathrm{C}\left(4^{\circ} \mathrm{C} \mathrm{min}-1\right)$ which was held for $10 \mathrm{~min}$. Ion source was operated at $70 \mathrm{eV}$, and mass spectra were acquired in scan mode in the $50-550 \mathrm{~m} / \mathrm{z}$ range. Essential oil components were identified by comparing their retention indices and mass spectra with those published by Adams (2007) and with Wiley and NIST/NBS mass spectral libraries. A mixture of $n$-alkanes from $n$-octane (C8) to eicosane (C20) was used for calculation of Kovats retention indices (KI). ChemStation software (Agilent Technologies) was used for data analysis, and curves used for experimental estimation of KI were plotted and drawn using SciDaVis software.

\subsection{Preparation of rosemary extract}

Extract of R. officinalis was prepared from $10 \mathrm{~g}$ of milled herba extracted using maceration technique with $50 \mathrm{~mL}$ of $80 \%$ aqueous methanol, during $24 \mathrm{~h}$ at $4{ }^{\circ} \mathrm{C}$. After filtration, the solvent was evaporated at $40^{\circ} \mathrm{C}$ and concentrated to dryness under vacuum. Obtained dried extract was used for analyses of polyphenolic compounds and cell growth activity tests.

\subsection{Extraction and determination of phenolic compounds using HPLC-DAD-MS analysis}

Dried extract was dissolved in $80 \%$ methanol containing $1 \%$ $(w / v)$ 2.6-di-tert-butyl-4-methylphenol (BHT) to prevent oxidation in a cooled ultrasonic bath for $1 \mathrm{~h}$ (final concentration of the extract was $0.2 \mathrm{~g} \mathrm{~mL}^{-1}$ ). Obtained extract (in six replications) was centrifuged for $10 \mathrm{~min}$ at $1118 \times \mathrm{g}$. Each supernatant was filtered through the Chromafil AO-20/25 polyamide filter produced by Macherey-Nagel (Düren, Germany) and transferred to a vial prior to injection into the HPLC (high performance liquid chromatography) system. The solutions were kept at $-80{ }^{\circ} \mathrm{C}$ until further analysis. Phenolic compounds were analyzed on a Thermo Finnigan Surveyor HPLC system (Thermo Scientific, San Jose, USA) with a diode array detector at $280 \mathrm{~nm}$ (cinnamic acid derivatives and flavanols) and 350 $\mathrm{nm}$ (flavonols and flavones). Spectra of the compounds were recorded between 200 and $600 \mathrm{~nm}$. The column was a Gemini C18 $(150 \times 4.6 \mathrm{~mm}, 3 \mu \mathrm{m}$; Phenomenex, Torrance, USA) operated at $25{ }^{\circ} \mathrm{C}$. The elution solvents were aqueous $0.1 \%$ formic acid in twice distilled water (A) and $0.1 \%$ formic acid in acetonitrile (B). Samples were eluted according to the linear gradient from $5 \%$ to $20 \% \mathrm{~B}$ in the first $15 \mathrm{~min}$, followed by a linear gradient from $20 \%$ to $30 \%$ B for $5 \mathrm{~min}$, then an isocratic mixture for $5 \mathrm{~min}$, followed by a linear gradient from $30 \%$ to $90 \%$ B for $5 \mathrm{~min}$, and then an isocratic mixture for $15 \mathrm{~min}$ before returning to the initial conditions (Wang et al., 2002). The injection volume was $20 \mu \mathrm{L}$ and flow rate was $0.6 \mathrm{~mL}$ $\min ^{-1}$.

Polyphenolic compounds were identified by an HPLC Finnigan MS detector and an LCQ Deca XP MAX (Thermo Finigan, San Jose, CA) instrument with electrospray interface (ESI) operating in negative ion mode. The analyses were carried out using full scan data-dependent MSn scanning from $\mathrm{m} / \mathrm{z} 110$ to 1500 . Column and chromatographic conditions were identical to those used for the HPLC-DAD analyses. The injection volume was $10 \mu \mathrm{L}$ and the flow rate $0.6 \mathrm{~mL} \mathrm{~min}^{-1}$. The capillary temperature was $250{ }^{\circ} \mathrm{C}$, the sheath gas was 60 units and auxiliary gas 15 units; the source voltage was $3 \mathrm{kV}$ and normalized collision energy was between 20-35\%. Spectral data were elaborated using the Excalibur software (Thermo Scientific).

The identification of compounds was confirmed by comparing retention times and their spectra, as well as by adding the standard solution to the sample and by fragmentation (Tables 2 and 3). Concentrations of phenolic compounds were calculated from peak areas of the sample and the corresponding standards and expressed in $\mathrm{mg} 100 \mathrm{~g}^{-1}$ dry weight (DW). For 
compounds lacking standards, quantification was carried out using compounds with structural similarities.

\subsection{Total Phenolic Compounds (TPC) Assay}

Quantification of TPC in rosemary extract (prepared using the same way as the one for HPLC analysis, but without BHT) was performed using spectrophotometer UV/Visible Evolution 220 (Thermo Scientific, San Jose, USA). TPC was determined by Folin-Ciocalteu method (Mikulic-Petkovsek et al., 2013) Tubes with $8.4 \mathrm{~mL} \mathrm{H}_{2} \mathrm{O}, 0.5 \mathrm{~mL} \mathrm{33 \%}$ Folin-Ciocalteu phenol reagent and $0.1 \mathrm{~mL}$ extract (except in blank) were vortexed and after 3-6 $\mathrm{min} 1 \mathrm{~mL}$ of $20 \% \mathrm{Na}_{2} \mathrm{CO}_{3}$ was added. Absorbance was recorded at $\lambda=765 \mathrm{~nm}$ after $1 \mathrm{~h}$ of incubation at room temperature. TPC was expressed as gallic acid equivalents (GAE) in $\mathrm{mg} \mathrm{g}^{-1}$ dry weight (DW).

\subsection{Cytotoxic activity of rosemary extract, effect on growth and culture of the cell lines}

For the estimation of cell growth activity, one non-transformed human cell line MRC-5 (fetal lung fibroblast, ECACC 84101801) and three human malignant transformed cell lines: MCF-7 (breast adenocarcinoma ECACC No. 86012803), HeLa (cervix epitheloidcarcinoma, ECACC No. 93021013) and HT29 (colon adenocarcinoma, ECACC No. 91072201) were used. The cell lines were grown and maintained in Dulbecco's Modified Eagle's Medium - DMEM (Sigma-Aldrich, USA) medium supplemented with Fetal Calf Serum - FCS (10\%), penicillin $\left(100\right.$ Units $\left.\mathrm{mL}^{-1}\right)$ and streptomycin $\left(100 \mu \mathrm{g} \mathrm{mL} \mathrm{m}^{-1}\right)$, being referred to as complete medium. The cells were cultured in 25 $\mathrm{cm}^{2}$ flasks at $37^{\circ} \mathrm{C}$ in the atmosphere of $5 \% \mathrm{CO}_{2}$ and high humidity, and sub-cultured twice a week. A single cell suspension was obtained using $0.1 \%$ trypsin with $0.04 \%$ EDTA. Cell growth was evaluated by the colorimetric sulforhodamine B (SRB) assay (Rubinstein et al., 1990). Cell lines were plated into 96-well microtiter plates (Sarstedt, Newton, USA) at different seeding density of $5 \times 10^{3}$ cells per well for MRC- 5 and MCF-7, $4 \times 10^{3}$ cells for HeLa and $6 \times 10^{3}$ cells for HT-29 in a volume of $180 \mu \mathrm{L}$, and pre-incubated in complete medium supplemented with $5 \% \mathrm{FCS}$, at $37^{\circ} \mathrm{C}$ for $24 \mathrm{~h}$.

For the evaluation of the cell growth activity, dry extract of Rosmarinus officinalis was diluted in mixture of DMSO and 0.9\% $\mathrm{NaCl}$ to obtain final concentrations in range of 500-1000 $\mu \mathrm{g}$ $\mathrm{mL}^{-1}$ while in control cell group, mixture of DMSO and $0.9 \%$ $\mathrm{NaCl}$ were added (DMSO concentration was under $0.2 \%$ ).

For the co-treatment we have chosen antitumor drug BLM. For investigations of co-effect of rosemary extract and BLM on cell lines growth, the chosen final concentration of BLM was $100 \mu \mathrm{g} \mathrm{mL} \mathrm{m}^{-1}$. This concentration of BLM was chosen because higher concentrations of BLM can induce very high frequency of micronuclei (MN), which was difficult to score accurately. Serial dilutions of rosemary extract and BLM (20 $\mu \mathrm{L}$ well ${ }^{-1}$ ) were added to achieve required final concentrations. Microplates were then incubated at $37^{\circ} \mathrm{C}$ for an additional 48 h. Colour development was measured using Multiscan Ascent (Labsystems; Helsinki, Finland) photometer at $540 \mathrm{~nm}$ against $620 \mathrm{~nm}$ as background. Results of cell growth activity were expressed as mean \pm SD of three independent experiments, performed in quadruplicate.

The effect on cell growth was expressed as a percent of the control and calculated as: (At/Ac) $\times 100(\%)$, where At is the absorbance of the test sample and Ac is the absorbance of the control (Četojević Simin et al., 2015). Based on concentrationcell growth curves, $\mathrm{EC}_{50}$ values (concentration that inhibit cell growth by $50 \%$ ) were determined using CalcuSyn Version 1.1 (Mike Hayball, Copyright Biosoft, 1996). Using EC 50 values obtained in a non-tumor cell line and in the respective tumor cell line, non-tumor/tumor $\mathrm{EC}_{50}$ ratios $(\mathrm{NT} / \mathrm{T})$ were calculated for extract, combination of extract and drug. NT/T ratio shows the efficiency of tested material effect on tumour cells in comparison to healthy ones (Četojević Simin et al., 2015).

\subsection{Statistical analysis}

Values of biochemical parameters and the cell growth activity were expressed as means \pm standard error of determinations made in triplicates and quadruplicate, respectively. Results were tested by ANOVA followed by comparisons of means by the Duncan's test $(\mathrm{P}<0.05)$. Statistical analyses were performed using STATISTICA for Windows version 13 (Dell Software) and CalcuSyn Version 1.1 (Mike Hayball, Copyright Biosoft, 1996).

\section{RESULTS}

Plant material tested in this study belongs to Spanish type of rosemary according to International Standard of rosemary essential oil (ISO 1342, 2012). The yield of essential oil in the above-ground parts of examined specimen (1.9\% of rosemary dry weight) permit the assignment of this species to oil-rich representatives of the Lamiaceae family. Bearing in mind that the yield of the hydrodistillation is much lower compared to steam distillation, the yield of our sample was much higher in comparison to the Algerian rosemary $(0.4 \%)$, but lower in comparison to the Iranian sample (2.6\%) (Boutekedjiret et al., 2003; Jamshidi et al., 2009).

Table 1. Essential oil composition of the rosemary herba

\begin{tabular}{lrr} 
Compound name & $\mathrm{RI}$ & $\% \mathrm{~m} / \mathrm{m}$ \\
\hline$\alpha$-Thujene & 932 & 0.31 \\
$\alpha$-Pinene & 940 & 13.41 \\
Camphene & 955 & 4.36 \\
$\beta$-Pinene & 983 & 3.95 \\
Myrcene & 992 & 5.64 \\
$\alpha$-Phellandrene & 1009 & 0.43 \\
Carene 3-delta & 1014 & 1.63 \\
$\alpha$-Terpinene & 1020 & 0.46 \\
$p$-Cymene & 1028 & 0.70 \\
1,8-Cineole & 1035 & 32.99 \\
$\gamma$-Terpinene & 1064 & 0.79 \\
Terpinolene & 1090 & 1.02 \\
Linalool & 1100 & 1.43 \\
Camphor & 1144 & 15.55 \\
Borneol & 1167 & 3.17 \\
Terpinen-4-ol & 1179 & 0.97 \\
$\alpha$-Terpineol & 1190 & 2.54 \\
Verbenone & 1206 & 1.88 \\
Bornyl acetate & 1287 & 2.60 \\
Caryophyllene Z & 1406 & 3.08 \\
$\alpha$-Humulene & 1456 & 0.59 \\
Caryophyllene oxide & 1582 & 0.97 \\
Total identified compounds & $/$ & 98.47 \\
\hline & & \\
\hline
\end{tabular}

The composition of the essential oil is summarized in Table 1. The percentage of identified components in the oil sample 
was $98.47 \%$. Of the 22 components detected, all of them were identified in the oil in amount higher than $0.1 \%$. The sample contained predominantly monoterpenes (93.8\%), in which 1.8 cineol $(32.9 \%)$ and camphor $(15.5 \%)$ were the dominant compounds. A considerable amount of some other monoterpene compounds was also identified: $\alpha$-pinene $(13.4 \%)$, myrcene $(5.6 \%)$, camphene $(4.3 \%), \beta$-pinene $(3.9 \%)$, and borneol $(3.2 \%)$. Relative portion of sesquiterpenes was low (4.6\%) with the caryophyllene $\mathrm{Z}$ as the dominant component (3.1\%).

The major polyphenolic constituents in investigated rosemary herba were flavones, flavonols and phenolic acids. As it is shown in Table 2, most of the phenolic acids were hydroxycinnamic acids derivatives (caffeic and quinic acid derivatives). Caffeic acid ester and rosmarinic acid derivatives were present in the highest amount $\left(69.2 \mathrm{mg} 100 \mathrm{~g}^{-1}\right)$.

A scale according to the content of flavones and flavonols can be organised in the following order: luteolin $>$ isorhamnetin $>$ quercetin $>$ kaempferol $>$ apigenin (Table 3). Beside these, low amounts of lignin medioresinol derivatives (0.4 mg $100 \mathrm{~g}-1)$, as well as phenolic terpene epirosmanol (0.9 $\mathrm{mg} 100 \mathrm{~g}^{-1}$ ) isomers were also detected (Table 2). According to our results TPC in investigated extract was $6.3 \mathrm{~g} \mathrm{GA} 100$ $\mathrm{g}^{-1}$, whereas the most abundant were luteolin-3-glucuronide derivatives (Table 3).

The antitumor activity of rosemary extract without and with BLM was evaluated in vitro by the colorimetric sulforhodamine B (SRB) assay using human non-tumor MRC-5 and three tumor cell lines MCF-7, HeLa and HT-29 (Figure 1). Rosemary extract showed moderate activity regarding the cell growth inhibition with $\mathrm{EC}_{50}$ values between 344.3 and 461.5 $\mu \mathrm{g} \mathrm{m}^{-1}$ (Table 4). There was no selective antiproliferative activity of rosemary extract towards tumor cells in comparison to non-tumor ones (NT/T ratio for all cancer cell line was lower than 1). The most susceptible tumor cell line regarding Rosemary effect was HeLa $\left(\mathrm{EC}_{50} 385.2 \mu \mathrm{g} \mathrm{mL}^{-1}\right)$, then MCF7 , while the lowest antitumor activity rosemary showed on HT-29. Tested cell lines proved to have the same susceptibility. Concentration-dependent effect was achieved experimentally, by applying different concentrations of rosemary and BLM. The antiproliferative activity at co-treatment was higher from those with BLM only in MCF-7 cells $\left(\mathrm{EC}_{50}\right.$, rosemary+BLM : BLM $=58.9$ : 119.8) (Table 4).

Antitumor activity of rosemary extract in combination with BLM was higher in comparison to effect of extract solely on all cell lines. Among tumour cells, most susceptible were MCF7 (7-fold more than for rosemary extract), then HeLa cells (2.3-fold more than for rosemary extract), while HT-29 cells were the least susceptible (1.58-fold more than for rosemary extract). NT/T ratio was 1.0 for HeLa and 2.9 for MCF-7 cells, pointing to moderate selective response of rosemary extract in combination with BLM regarding the breast adenocarcinoma tumour type.

\section{DISCUSSION}

Regarding the investigations about combined administration of natural compounds and antineoplastic drugs, there are comprehensive possible benefits of such therapy. They might be reflected through lowering the dosage of conventional medicines and consequently decreasing the toxicity of antineoplastic drugs on healthy cells followed by higher cytotoxic effects toward cancer cells. Authentic samples of essential oil of rosemary harvested in coastal areas of California, Corsica, Croatia or Haute Provence differ significantly in their respective content of cineole, camphor, bornyl acetate and verbenone. Samples with low camphor and high verbenone contents are referred to as "rosemary verbenone" (California, Corsica) (Schnaubelt, 2011). This oil has been recognized for its specific mucolytic properties and its usefulness for skin care formulas. The Haute Provence variety with high cineole and high camphor content is used in aromatherapy as well as for its expectorant and anti-infectious effects. Rosemary essential oil from the islands of the Adriatic coast of Croatia has a composition squarely in the middle, with a camphor content of approximately $10 \%$. Our result for camphor content $(15.5 \%)$ is somewhat above this, presumably because the Krk Island is located in the North of the Adriatic Sea and very close to mountainous mainland, with strong cold winds during winter and spring. It is known that camphor and $\alpha$-pinene have been related to antioxidant activities (Sedighi et al., 2015), whereas antiproliferative activity has been ascribed to 1,8 cineol even for antiproliferative effect, leading to apoptosis in the leukemia cell (Kladniew et al., 2014).

The content and composition of phenolic compounds is very important due to their antitumor activity. For example, flavones act against cancer through antioxidant reactions in cells (Ren et al., 2003). Furthermore, their role in inhibition of angiogenesis, promotion and differentiation, as well as in apoptosis is well defined (Ren et al., 2003; Ivanova et al., 2014b). Also, flavonoids can play sensitizing role in malignant cells exposed to conventional chemotherapeutics through modifying the molecular events that control the cell growth, differentiation and programmed cell death (Ivanova et al., 2014b). Among the flavons and flavonols in the examined extract, the most common are luteolin-3-glucuronide derivatives. More recent studies highlight luteolin as a compound with strong selective anticancer activity that potentiates with dose increase (Goodarzi et al., 2018; Seydi et al., 2018).

Some authors (Munné-Bosch et al., 2000) reported that isorosmanol, rosmanol, carnosol, 11,12-di-O-methylisorosmanol, carnosic acid and 12-O-methylcarnosic acid are main phenolic diterpens found in leaves of rosemary grown in the Mediterranean region. However, their investigations concluded that content of phenolic diterpens varies during the vegetation season, as well as due to some abiotic factors, such as: relative water content of the leaf, high solar radiation and temperature. Rosemary plants subjected to enhanced water deficit, salinity, intense light, and heat stress seem to have lower carnosic acid concentrations (Tounekti and Munné-Bosch, 2012), which could explain the deficit of these compounds in our samples. Extract used in this study, as opposed to the low concentration of carnosic acid, is characterized with presence of other biologically active components, among which mostly flavons, as well as caffeic and rosmarinic acid derivatives.

Previous study showed that rosmarinic acid has low cytotoxic effect on cell lines and low effect on the cell viability (YesilCeliktas et al., 2010). Caffeic acid initiates the fibrosarcoma cancer cell death by decreasing cell proliferation, increasing intracellular reactive oxygen species (ROS), alteration in mitochondrial membrane potential, lipid peroxidation, DNA damage and apoptosis (Prasad et al., 2011). Also, caffeic acid phenethyl ester has a possibility to induce apoptosis via Fas signal activation in human breast cancer MCF-7 cells (Watabe et al., 2004). It is known that rosmarinic acid blocks the proliferation induced by tumor necrosis factor-alpha or plateletderived growth factor (PDGF). These effects occur at both the G0-G1 and G1-S phases of cell division (Makino et al., 2000). Present investigation confirmed that methanol extract of rosemary, with proven predominant flavons and derivatives of caffeic and rosmarinic acid, led to a moderate inhibition of cell growth for all investigated cell lines, with cervix carcinoma cell line as the most susceptible to the activity of the extract, and colon carcinoma cell line as the least susceptible.

The study of Borrás-Linares et al. (2015) on colon adenocarcinoma HT-29 and SW480 cells investigated the comparative antiproliferative and cytotoxic feature of rosemary and its fractions with review on their potential synergistic ef- 
Table 2. Characterisation and content of phenolic acids and other polyphenols in rosemary herba (results are presented as mean \pm standard deviation)

\begin{tabular}{|c|c|c|c|c|}
\hline Rt (min) & {$[\mathrm{M}-\mathrm{H}]^{-}(m / z)$} & $\mathrm{MS}^{2}[\mathrm{M}-\mathrm{H}]^{-}(m / z)$ & Tentative identification & mg per $100 \mathrm{~g}^{-1} \mathrm{DW}$ \\
\hline 12.2 & 341 & $179,281,251$ & caffeoyl-hexoside derivative 1 & $2.24 \pm 0.09$ \\
\hline 13.2 & 341 & $281,251,179$ & caffeoyl-hexoside derivative 2 & $7.97 \pm 1.10$ \\
\hline 15.0 & 353 & $179,173,191,136$ & 4-O-caffeoylquinic acid derivative 1 & $0.15 \pm 0.00$ \\
\hline 16.4 & 353 & $179,173,191,136$ & 4-O-caffeoylquinic acid derivative 2 & $0.29 \pm 0.00$ \\
\hline 19.4 & 371 & 353 & caffeic acid derivative & $0.91 \pm 0.00$ \\
\hline 26.4 & 677 & $515,353,329,509,191$ & 1,3,5-tri-O-caffeoylquinic acid & $0.94 \pm 0.00$ \\
\hline 15.0 & 387 & 207 & medioresinol derivative 1 & $0.12 \pm 0.00$ \\
\hline 15.1 & 387 & 207 & medioresinol derivative 2 & $0.24 \pm 0.00$ \\
\hline 36.1 & 359 & $161,197,225$ & rosmarinic acid derivative 1 & $59.85 \pm 2.31$ \\
\hline 34.5 & 359 & $161,197,314$ & rosmarinic acid derivative 2 & $0.85 \pm 0.01$ \\
\hline 35.4 & 359 & $161,197,314$ & rosmarinic acid derivative 3 & $0.50 \pm 0.00$ \\
\hline 25.4 & 549 & 387,489 & rosmarinic acid derivative 5 & $3.94 \pm 1.13$ \\
\hline 21.6 & 521 & $359,161,197$ & rosmarinic acid hexoside & $1.05 \pm 0.07$ \\
\hline 32.7 & 299 & 137 & hydrobenzoic acid hexoside & $4.62 \pm 0.07$ \\
\hline 33.8 & 345 & 301,283 & epirosmanol derivative 1 & $3.54 \pm 0.06$ \\
\hline 33.9 & 345 & 301,283 & epirosmanol derivative 2 & $1.86 \pm 0.03$ \\
\hline
\end{tabular}

Table 3. Characterisation and content of flavones and flavonols in rosemary herba (results are presented as mean \pm standard deviation)

\begin{tabular}{|c|c|c|c|c|}
\hline $\operatorname{Rt}(\min )$ & {$[\mathrm{M}-\mathrm{H}]^{-}(m / z)$} & $\mathrm{MS}^{2}[\mathrm{M}-\mathrm{H}]^{-}(m / z)$ & Tentative identification & mg per $100 \mathrm{~g}^{-1} \mathrm{DW}$ \\
\hline 16.9 & 593 & 503,491 & apigenin-6,8-C-diglucoside (vicenin II) & $1.63 \pm 0.02$ \\
\hline 23.0 & 597 & 447,285 & luteolin-rhamnoglucoside (luteolin-7-rutinoside) & $16.17 \pm 0.12$ \\
\hline 24.2 & 461 & 285 & luteolin-3-glucuronide 1 & $16.47 \pm 0.14$ \\
\hline 25.3 & 461 & 285 & luteolin-3-glucuronide 2 & $13.55 \pm 0.09$ \\
\hline 27.6 & 461 & 285 & luteolin-3-glucuronide 3 & $85.28 \pm 0.19$ \\
\hline 17.2 & 503 & 285,399 & luteolin-3-O-(O-acetyl)- $\beta$-D-glucuronide derivative 1 & $12.02 \pm 0.07$ \\
\hline 30.8 & 503 & 285,399 & luteolin-3-O-(O-acetyl)- $\beta$-D-glucuronide derivative 2 & $44.73 \pm 0.21$ \\
\hline 31.8 & 503 & 285,399 & luteolin-3-O-(O-acetyl)- $\beta$-D-glucuronide derivative 3 & $62.81 \pm 1.30$ \\
\hline 32.1 & 503 & 285,443 & luteolin-3-O-(O-acetyl)- $\beta$-D-glucuronide derivative 4 & $49.84 \pm 1.24$ \\
\hline 31.5 & 607 & 299 & diosmetin-8-C-rhamnosyl-7-O-glucoside (diosmin) & $20.02 \pm 0.14$ \\
\hline 25.6 & 609 & 447,285 & kaempferol-3,7-di-O-glucoside & $8.27 \pm 0.02$ \\
\hline 22.0 & 593 & 285 & kaempferol-3-O-rutinoside & $5.14 \pm 0.01$ \\
\hline 12.8 & 477 & 315 & isorhamnetin hexoside & $5.95 \pm 0.05$ \\
\hline 23.5 & 477 & 315,301 & isorhamnetin-3-O-hexoside derivative 1 & $31.37 \pm 1.10$ \\
\hline 25.7 & 477 & 315,301 & isorhamnetin-3-O-hexoside derivative 2 & $2.32 \pm 0.04$ \\
\hline 24.8 & 491 & 315,300 & isorhamnetin-3-O-glucuronide & $2.72 \pm 0.09$ \\
\hline 25.9 & 639 & $477,315,300$ & isorhamnetin-3,7-diglucoside & $10.81 \pm 1.12$ \\
\hline 22.7 & 623 & $315,299,477$ & isorhamnetin-3-O-rhamnosyl hexoside derivative 1 & $3.94 \pm 0.07$ \\
\hline 27.1 & 623 & 315,300 & isorhamnetin-3-O-rhamnosyl hexoside derivative 2 & $3.50 \pm 0.06$ \\
\hline 27.8 & 623 & 315,300 & isorhamnetin-3-O-rhamnosyl hexoside derivative 3 & $6.09 \pm 0.07$ \\
\hline 19.9 & 609 & 301 & quercetin-3-rhamnosyl hexoside derivative 1 & $4.99 \pm 0.03$ \\
\hline 24.5 & 609 & 301 & quercetin-3- rhamnosyl hexoside derivative 2 & $16.47 \pm 0.09$ \\
\hline 20.5 & 463 & 301 & quercetin-3-O-glucoside & $8.72 \pm 0.13$ \\
\hline 23.9 & 625 & 301,463 & quercetin-dihexoside & $16.47 \pm 0.17$ \\
\hline 27.8 & 653 & 315,300 & quercetin-diglucuronide & $8.78 \pm 0.07$ \\
\hline
\end{tabular}

fects. The phenomenon of synergism was also investigated by Lewandowska et al. (2014), who presented a review of studies which confirms that rosemary constituents potentiate the effectiveness of conventional chemotherapeutics, as well as other compounds of plant origin, on MCF7 and HT29 cell lines. Previous data indicate that low-toxic conventional synthetic antioxidants, as well as antioxidant constituents from rosemary and other plants may have important role in process of sensitization of irradiated and chemotherapeutic-treated tumor cells (Plouzek et al., 1999; Berdowska et al., 2013; Ivanova et al., 2014b). Berdowska et al. (2013) confirmed the antiproliferative activity of polyphenol plant extract components on adriamycin resistant MCF-7 cells through MTT test. It is interesting that tested polyphenolics exhibited more beneficial 


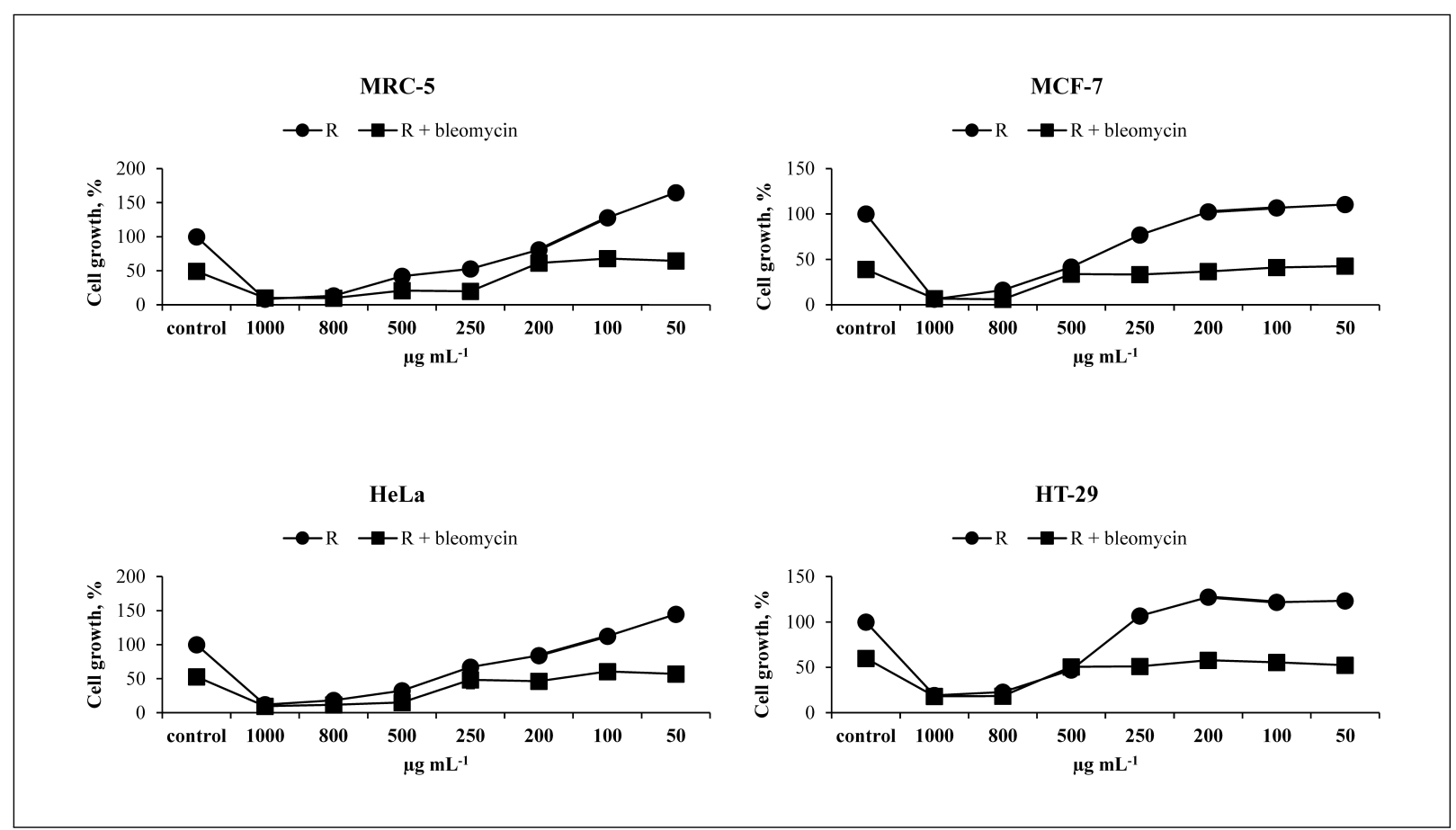

Fig. 1. Effect of rosemary with and without bleomycin $\left(100 \mu \mathrm{g} \mathrm{mL}^{-1}\right)$ on growth of cell lines at $48 \mathrm{~h}$ treatment. Results are shown as mean \pm standard deviation of three independent experiments, performed in quadruplicate.

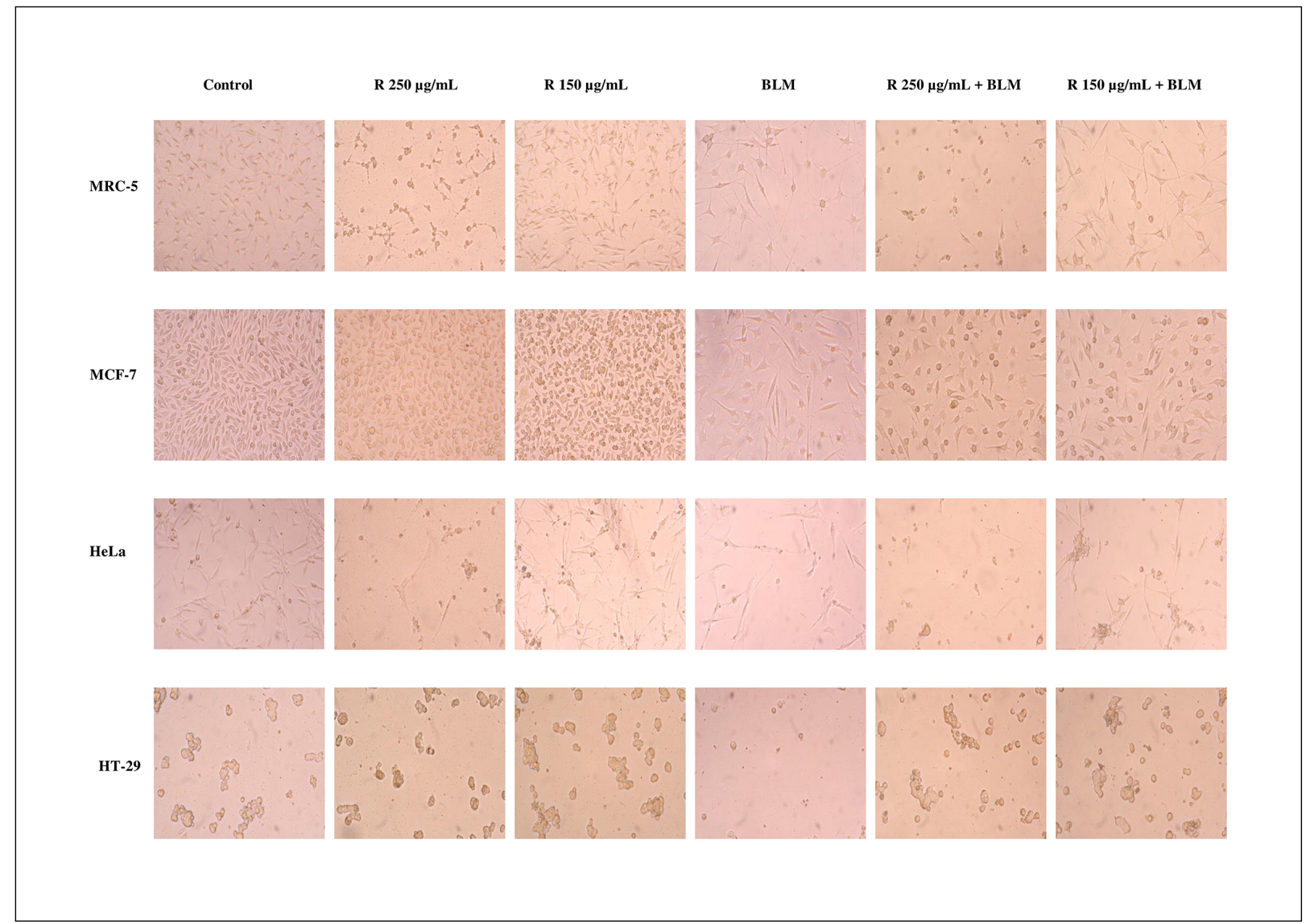

Fig. 2. Appearance of cells treated by rosemary with and without bleomycin $\left(100 \mu \mathrm{g} \mathrm{mL}^{-1}\right)$ during $48 \mathrm{~h}$ treatment, (magnification $\left.400 x\right)$. Rrosemary extract, BLM-bleomycin

properties when they were applied in the form of extracts comprising their mixtures than individually (Berdowska et al., 2013).

\section{CONCLUSION}

Results of this study showed that the major polyphenolic constituents in investigated rosemary extract were phenolic acids (rosmarinic acid and its derivatives), as well as flavones and flavonols in the following order: luteolin $>$ isorhamnetin $>$ quercetin $>$ kaempferol $>$ apigenin. Regard- 
Table 4. $\mathrm{EC}_{50}$ values $\left(\mu \mathrm{g} \mathrm{ml}^{-1}\right)$ and non-tumor/tumor $\mathrm{EC}_{50}$ ratios $(\mathrm{NT} / \mathrm{T})$ in human cell lines.

\begin{tabular}{lrrr}
\hline Cell line & $\mathrm{R}^{\mathrm{a}}$ & $\mathrm{R}+\mathrm{BLM}$ & $\mathrm{BLM}$ \\
\hline MRC-5 & 344.32 & 170.81 & 80.3 \\
MCF-7 & 407.91 & 58.6 & 119.81 \\
HeLa & 385.15 & 162.85 & 77.2 \\
HT-29 & 461.54 & 291.27 & 165.31 \\
\hline MCF-7 (NT/T) & 0.84 & 2.91 & 0.67 \\
HeLa (NT/T) & 0.89 & 1.05 & 1.04 \\
HT-29 (NT/T) & 0.75 & 0.59 & 0.49 \\
\hline
\end{tabular}

${ }^{a} \mathrm{EC}_{50}$ values for effect of rosemary extract $(\mathrm{R})$ and bleomycin were established for bleomycin (BML) concentration of $100 \mathrm{\mu g} \mathrm{ml}^{-1}$

ing the antiproliferative activity, we confirmed that treatment with rosemary extract led to moderate inhibition of cell growth for all investigated cell lines, where the most susceptible to rosemary effect was cervix carcinoma cell line, and the least susceptible was colon carcinoma cell line. The antiproliferative activity at co-treatment was higher from those with BLM in breast cancer cells alone. This combination also potentiates the antiproliferative effect of rosemary extract in all investigated cancer cell lines, with 7 times increased effect on breast cancer cells compared to the effect of rosemary extract alone. Co-treatment with BLM causes moderate selectivity to breast and cervical cancer cells compared to healthy cells.

To the best of our knowledge, this study represents the first report on the antiproliferative effects of combination of rosemary extract and antineoplastic drug bleomycin, in spite of their wide single use and numerous studies on the subject. Considering these conclusions and our present results, we suggest the usage of rosemary extract in combination with the standard chemotherapeutics, for further studious investigations on a variety of human cancer cell lines.

\section{ACKNOWLEDGMENTS}

This work was supported by the Ministry of Education, Science and Technological Development of the Republic of Serbia (grant number 175056).

\section{REFERENCES}

Adams, R. (2007). Identification of essential oil components by gas chromatography/mass spectrometry (Vol. 456), Carol Stream, IL: Allured Publishing Corporation.

Alexandrov, K., Rojas, M. and Rolando, C. (2006). DNA Damage by benzo(a)pyrene in human cells is increased by cigarette smoke and decreased by a filter containing rosemary extract, which lowers free radicals, Cancer Research 66(24): 11938-11945.

Ali, B., Al-Wabel, N. A., Shams, S., Ahamad, A., Khan, S. A. and Anwar, F. (2015). Essential oils used in aromatherapy: A systemic review, Asian Pacific Journal of Tropical Biomedicine 5(8): 601-611.

Berdowska, I., Zieliński, B., Fecka, I., Kulbacka, J., Saczko, J. and Gamian, A. (2013). Cytotoxic impact of phenolics from Lamiaceae species on human breast cancer cells, Food Chemistry 141(2): 1313-1321.

Bittner Fialová, S., Kello, M., Čoma, M., Slobodníková, L., Drobná, E., Holková, I., Garajová, M., Mrva, M., Zachar, V. and Lukáč, M. (2019). Derivatization of rosmarinic acid enhances its in vitro antitumor, antimicrobial and antiprotozoal properties, Molecules 24(6): 1078.
Borrás-Linares, I., Pérez-Sánchez, A., Lozano-Sánchez, J., Barrajón-Catalán, E., Arráez-Román, D., Cifuentes, A., Micol, V. and Carretero, A. S. (2015). A bioguided identification of the active compounds that contribute to the antiproliferative/cytotoxic effects of rosemary extract on colon cancer cells, Food and Chemical Toxicology 80: 215-222.

Boutekedjiret, C., Bentahar, F., Belabbes, R. and Bessiere, J. M. (2003). Extraction of rosemary essential oil by steam distillation and hydrodistillation, Flavour and Fragrance Journal 18(6): 481-484.

Cheung, S. and Tai, J. (2007). Anti-proliferative and antioxidant properties of rosemary Rosmarinus officinalis, Oncology Reports .

Četojević Simin, D., Velićanski, A., Cvetković, D., Markov, S., Ćetković, G., Šaponjac, V., Vulić, J., Čanadanović Brunet, J. and Đilas, S. (2015). Bioactivity of meeker and willamette raspberry (Rubus idaeus 1.) pomace extracts, Food Chemistry 166: 407-413.

González-Vallinas, M., Molina, S., Vicente, G., de la Cueva, A., Vargas, T., Santoyo, S., Garcia-Risco, M., Fornari, T., Reglero, G. and de Molina, A. (2013). Antitumor effect of 5 -fluorouracil is enhanced by rosemary extract in both drug sensitive and resistant colon cancer cells., Pharmacological Research 72: 61-68.

González-Vallinas, M., Molina, S., Vicente, G., SánchezMartínez, R., Vargas, T., García-Risco, M., Fornari, T., Reglero, G. and Ramirez de Molina, A. (2014). Modulation of estrogen and epidermal growth factor receptors by rosemary extract in breast cancer cells, Electrophoresis 35(11): 1719-1727.

Goodarzi, S., Tabatabaei, M. J., Mohammad Jafari, R., Shemirani, F., Tavakoli, S., Mofasseri, M. and Tofighi, Z. (2018). Cuminum cyminum fruits as source of luteolin-7-O-glucoside, potent cytotoxic flavonoid against breast cancer cell lines, Natural Product Research 18: 1-5.

Haddad, A. Q., Venkateswaran, V., Viswanathan, L., Teahan, S. J., Fleshner, N. E. and Klotz, L. H. (2006). Novel antiproliferative flavonoids induce cell cycle arrest in human prostate cancer cell lines, Prostate Cancer and Prostatic Diseases 9(1): 6876.

Han, Y., Ma, L., Zhao, L., Feng, W. and Zheng, X. (2019). Rosmarinic inhibits cell proliferation, invasion and migration via up-regulating mir-506 and suppressing mmp2/16 expression in pancreatic cancer, Biomedicine $\mathcal{E}$ Pharmacotherapy 115: 108878.

Ivanova, D., Georgieva, E., Lazarova, D., Gadjeva, V., Bakalova, R. and Zhelev, Z. (2014a). Redox-modulating and/or antioxidant properties of niroxides-a potential reason for decreasing side-effects of cancer therapy, Trakia Journal of Sciences 13(3): 325

Ivanova, D., Georgieva, E., Lazarova, D., Gadjeva, V., Bakalova, R. and Zhelev, Z. (2014b). Redox-modulating and/or antioxidant properties of niroxides-a potential reason for decreasing side-effects of cancer therapy, Trakia Journal of Sciences 12(3): 329-337.

Jamshidi, R., Afzali, Z. and Afzali, D. (2009). Chemical composition of hydrodistillation essential oil of rosemary in different origins in Iran and comparison with other countries, American-Eurasian Journal of Agricultural and Environmental Sciences 5(1): 78-81. 
Kabouche, Z., Boutaghane, N., Laggoune, S., Kabouche, A., Ait-Kaki, Z. and Benlabed, K. (2005). Comparative antibacterial activity of five lamiaceae essential oils from Algeria, International Journal of Aromatherapy 15(3): 129-133.

Kladniew, B., Polo, M., Villegas, S., Galle, M., Crespo, R. and de Bravo, M. (2014). Synergistic antiproliferative and anticholesterogenic effects of linalool, 1,8-cineole, and simvastatin on human cell lines, Chemico-Biological Interactions 214: $57-68$.

Leal, P., Braga, M., Sato, D., Carvalho, J., Marques, M. and Meireles, M. (2003). Functional properties of spice extracts obtained via supercritical fluid extraction, Journal of Agricultural and Food Chemistry 51(9): 2520-2525.

Lewandowska, U., Gorlach, S., Owczarek, K., Hrabec, E. and Szewczyk, K. (2014). Synergistic interactions between anticancer chemotherapeutics and phenolic compounds and anticancer synergy between polyphenols, Advances in Clinical and Experimental Medicine 68.

Makino, T., Ono, T., Muso, E., Yoshida, H., Honda, G. and Sasayama, S. (2000). Inhibitory effects of rosmarinic acid on the proliferation of cultured murine mesangial cells, Nephrology Dialysis Transplantation 15(8): 1140-1145.

Mikulic-Petkovsek, M., Schmitzer, V., Slatnar, A., Weber, N., Veberic, R., Stampar, F., Munda, A. and Koron, D. (2013). Alteration of the content of primary and secondary metabolites in strawberry fruit by Colletotrichum nymphaeae infection, Journal of Agricultural and Food Chemistry 61(25): 59875995.

Munné-Bosch, S., Alegre, L. and Schwarz, K. (2000). The formation of phenolic diterpenes in Rosmarinus officinalis 1. under Mediterranean climate, European Food Research Technology 210(4): 263-267.

Okumura, N., Yoshida, H., Nishimura, Y., Kitagishi, Y. and Matsuda, S. (2012). Terpinolene, a component of herbal sage, downregulates AKT1 expression in K562 cells, Oncology Letters 3(2): 321-324.

Peng, Y., Yuan, J., Liu, F. and Ye, J. (2005). Determination of active components in rosemary by capillary electrophoresis with electrochemical detection, Journal of Pharmaceutical and Biomedical Analysis 39(3-4): 431-437.

Petiwala, S., Berhe, S., Li, G., Puthenveetil, A., Rahman, O., Nonn, L. and Johnson, J. (2014). Rosemary (Rosmarinus officinalis) extract modulates chop/gadd153 to promote androgen receptor degradation and decreases xenograft tumor growth, PLOS One 9(3): e89772.

Petiwala, S. and Johnson, J. (2015). Diterpens from rosemary (Rosmarinus officinalis): Defining their potential for anticancer activity, Cancer Letters 367(2): 93-102.

Ph.Eur.8.0 (2013). European Pharmacopoeia 8.0, Council of Europe, Strasbourg.

Plouzek, C., Ciolino, H., Clarke, R. and Yeh, G. (1999). Inhibition of p-glycoprotein activity and reversal of multidrug resistance in vitro by rosemary extract, European Journal of Cancer 35(10): 1541-1545.

Povirk, L. (1996). Dna damage and mutagenesis by radiomimetic dna-cleaving agents: bleomycin, neocarzinostatin and other enediynes, Mutation Research 355(1-2): 71-89.
Prasad, N., Karthikeyan, A., Karthikeyan, S. and Reddy, B. (2011). Inhibitory effect of caffeic acid on cancer cell proliferation by oxidative mechanism in human ht-1080 fibrosarcoma cell line, Molecular and Cellular Biochemistry 349(12): 11-19.

Ren, W., Qiao, Z., Wang, H., Zhu, L. and Zhang, L. (2003). Flavonoids: promising anticancer agents, Medicinal Research Reviews 23(4): 519-534.

Rubinstein, L., Shoemaker, R., Paull, K., Simon, R., Tosini, S., Skehan, P., Scudiero, D., Monks, A. and Boyd, M. (1990). Comparison of in vitro anticancer-drug-screening data generated with a tetrazolium assay versus a protein assay against a diverse panel of human tumor cell lines, Journal of the National Cancer Institute 82(13): 1113-1117.

Sancheti, G. and Goyal, P. (2006). Effect of Rosmarinus officinalis in modulating 7,12-dimethylbenz (a) anthracene induced skin tumorigenesis in mice, Phytotherapy Research 20(11): 981986.

Schnaubelt, K. (2011). The healing intelligence of essential oils: the science of advanced aromatherapy, Vermont: Inner Traditions/Bear \& Company.

Sedighi, R., Zhao, Y., Yerke, A. and Sang, S. (2015). Preventive and protective properties of rosemary (Rosmarinus officinalis 1.) in obesity and diabetes mellitus of metabolic disorders: a brief review, Current Opinion in Food Science 2: 58-70.

Seydi, E., Salimi, A., Rasekh, H., Mohsenifar, Z. and Pourahmad, J. (2018). Selective cytotoxicity of luteolin and kaempferol on cancerous hepatocytes obtained from rat model of hepatocellular carcinoma: involvement of rosmediated mitochondrial targeting, Nutrition and Cancer 70(4): 594-604.

Slameňová, D., Kubošková, K., Horváthová, E. and Robichová, S. (2002). Rosemary-stimulated reduction of dna strand breaks and fpg-sensitive sites in mammalian cells treated with $\mathrm{H}_{2} \mathrm{O}_{2}$ or visible light-excited methylene blue, Cancer Letters 177(2): 145-153.

Tai, J., Cheung, S., Wu, M. and Hasman, D. (2012). Antiproliferation effect of rosemary (Rosmarinus officinalis) on human ovarian cancer cells (in vitro), Phytomedicine 19(5): 436-443.

Tounekti, T. and Munné-Bosch, S. (2012). Enhanced phenolic diterpenes antioxidant levels through non-transgenic approaches, Critical Reviews in Plant Sciences 31(6): 505-519.

Wang, S., Zheng, W. and Galletta, G. (2002). Cultural system affects fruit quality and antioxidant capacity in strawberries, Journal of Agricultural and Food Chemistry 50(22): 6534-6542.

Watabe, M., Hishikawa, K., Takayanagi, A., Shimizu, N. and Nakaki, T. (2004). Caffeic acid phenethyl ester induces apoptosis by inhibition of NFkb and activation of fas in human breast cancer MCF-7 cells, The Journal of Biological Chemistry 279(7): 6017-6026.

Yesil-Celiktas, O., Sevimli, C., Bedir, E. and Vardar-Sukan, F. (2010). Inhibitory effects of rosemary extracts, carnosic acid and rosmarinic acid on the growth of various human cancer cell lines, Plant Foods for Human Nutrition 65(2): 158-163. 